A Training Program for Physics Teachers Based on Self-Learning Strategies and Its Effect on Their Technological Enlightenment and Productive Thinking

Assist. Prof.dr. Etmad Naji. Fayadh alzobai \& Dr. Sameerah Adnan Thrther A-Qaisi 


\section{A Training Program for Physics Teachers Based on Self-Learning Strategies and Its Effect on Their Technological Enlightenment and Productive Thinking}

Assist. Prof.dr. Etmad Naji. Fayadh alzobai

Assistant professor of Methods of Teaching physics, Center for Continuing

Education, University of Fallujah, Iraq

Dr.etmad.naji@uofallujah.edu.iq

Dr. Sameerah Adnan Thrther A-Qaisi

Lecturer of Methods of Teaching physics, College of Education for Pure Sciences, University of Anbar, Iraq

Sameraalqass@gmail.com

Received in April 11, 2021

Accepted in July 7, 2021

Abstract: This paper aims to construct a proposed training program according to selforganized learning strategies for physics teachers and its effect on their technological enlightenment and productive thinking. The sample consists of (32) teachers and schools; (16) teachers as an experimental sample and (16) as a control sample. The tools are prepared, which are the Enlightenment Technology Scale, which was adopted by (Faez, 2016) consisting of (60) items. The Researchers have prepared the Productive Thinking Test, which consists of two domains: The Critical Thinking Field, which consists of (15) and the Creative Thinking Domain consisting of (9) situations. The stability of productive thinking is $(0.88)$, and the results show that the proposed training program, according to some self-organized learning strategies, meets the training needs of the trainees with remarkable effectiveness to improve the level of their teaching and educational technological performance and achieve the desired goals. The training is influential in bringing about the transfer of training to their students in developing their attitudes towards self-learning. The recommendations are to; apply the training program to the applied students in colleges, reduce the burden on physics teachers, reduce the fear of physics and increase the efficiency of teaching and learning. 
Assist. Prof.dr. Etmad Naji. Fayadh alzobai \& Dr. Sameerah Adnan Thrther A-Qaisi

Volume (4) No. (4) 2021

Key words: Training program, self-organized learning strategies, Technological Enlightenment, Productive Thinking. 


\section{Introduction}

The success of education and its development depends mainly on the teacher who possesses a set of skills and techniques that help him to meet the various educational levels of students and the diversity of requirements. For achieving this, it is required to increase the attention and serious interest in training teachers during their teaching in order to improve and develop their performance and motivation towards education. Physics is a fertile field for training through variable situations that require awareness of the relationships between its elements. This subject needs a new approach and a new method (Al-Fawzan, 2008). The use of a training program based on selforganized learning strategies is a key for the success and development, as it occupies a prominent place in the progress of the scientific renaissance and education. This is because the scientific thinking and self-organized learning are the basis on which the numbers of individuals and the various educational programs must be built (Al-Amrani and Abbas, 2011: 100).

And after questioning the physics teachers about this strategy and both concepts of the technical enlightenment and productive thinking, it became clear that they have not heard of this concept before and have no knowledge of the activities that are used to teach productive thinking skills. Furthermore, they have not participated in a training course related to productive thinking. thus, many of them need training programs based on self-organized learning strategies and courses that related to the topic of technological enlightenment and productive thinking. As a result, realize a sense of the problem that needs to be solved and the desire to construct a training program for productive thinking for physics teachers. According to the invitation of educational supervisors, school administrations and the meetings with teachers electronically, they emphasize the secondary educational staff need the effective training programs for thinking and providing teachers with various thinking skills to improve their productive thinking and eventually raise the education to a level that keeps pace with the series of rapid changes and tremendous development. 


\section{Objectives}

1- Experimental studies are considered as one of the most scientific curricula which are implied the scientific methods. They are the most accurate scientific studies that can affect the relationships between study variables.

2- This study is considered as one of the studies of self-organized learning that can be applied in understanding the competencies of the $21^{\text {st }}$ century.

3- constructing a training program according to the self-organized learning strategy to highlight the importance of training for physics teachers in particular as a theoretical importance.

4- For the first time, a training program for physics teachers has been implemented in the preparation and Training Directorate in the Anbar Education Directorate, as far as the Researchers apprehend the theoretical importance.

5- The prepared program in this study helps curriculum developers in the Ministry of Education to design appropriate curricula for students according to the organized learning strategies as a practical importance.

6- It can prove its effectiveness in; the General Directorate of teachers' preparation, training and educational development to improve the quality of prepared training programs and direct teachers to adopt the modern methods of teaching as an applied importance.

7- Identifying the impact of the proposed training program on physics and productive thinking to teachers as well as a practical importance.

8- Granting a realistic and thoughtful perception of the methods of preparing and developing staff technologically enlightened faculty who are capable of keeping pace the scientific and technological development via implementing the prepared training program for them. 


\section{The study samples}

1- Constructing a proposed training program based on some self-organized learning strategies for physics teachers.

2- Identifying the impact of the proposed training program in the productive thinking of physics teachers.

\section{The hypothesis of the study}

- There is no statistically significant difference at the level of $(0.05)$ between the average grades of physics teachers who were trained according to the proposed training program (experimental group) and physics teachers who were not trained according to the training program (control group) in the technological enlightenment scale.

- There is no statistically significant difference at the level (0.05) between the average grades of physics teachers who were trained according to the proposed training program (experimental group) and physics teachers who were not trained according to the training program (control group) in the productive thinking test.

\section{Study samples:}

1- Spatial Limits: a group of physics teachers.

2- Human Limits: Physics teachers of both sexes.

3- Objective limits: self-organized learning strategies.

\section{Existing studies:}

\section{Training Program:}

- $\quad$ (Sakarneh 2011): It is a planned, organized and continuous process aims to; developing the skills and abilities of the trainees, increasing their knowledge, improving their behavior and attitudes, as well as enabling him to perform their job efficiently and effectively. (Al Sakarnah, 2011: 16) 
- The theoretical definition: It refers to a set of activities and experiences that are planned and implemented by those responsible for training in a specific subject, for a specific period of time with the purpose of developing the knowledge and skills of the trainees for achieving the goals that are set in accordance with their training requirements.

- Procedural definition: It is a set of knowledge, skills and training activities which are planned, organized and programmed in time to acquire the educational skills that aim to raising the performance level of physics teachers.

- Self-organized learning strategy:

- (pintrich \& et al 2000): It indicates to those processes that students use for themselves, using cognitive and metacognitive strategies, in addition to their willingness to adopt those strategies in order to control the learning process. (70, pintrich \& et al 2000)

- Theoretical definition: It means the plans that help the learner to acquire the educational material inside and outside the classroom in the least effort and time. This is done via organizing and arranging the location that is devoted to studying and summarizing the academic content through requesting assistance from (learning / peers / parents) where a record of homework can be kept in order to get self-evaluation of the student and give feedback from the teacher, and this will enhance his self-confidence and motivation for getting a major achievement.

- Procedural definition: it is the teachers' use of the experimental group of selflearning strategies, whose training was developed by the Researchers, as they taught their students according to the strategy.

- Impact: (Ibrahim, 2009) it is the ability of the operator under study to achieve a positive result, but if this result does not get a positive level, the operator may be one of the direct causes of negative repercussions (Ibrahim, 2009: 199) 
- The theoretical definition: The expected result that may appear on male and female teachers as an outcome of education and thinking after subjecting them to programs or studying an educational subject.

- Procedural definition: the difference in physics for male and female physics teachers after the training program is based on self-organization.

- Technological enlightenment (Sabry, 2003): It is (the technological literacy of the individual, that is, providing the individual with the minimum level of knowledge, skills and trends that enable him/ her to deal with the applications of modern and developed technology in a correct manner. Besides, the individual can interact with technique positively in a way that achieves the maximum benefit for self and his/her society. It also helps to draw for him/ her the moral and social limits in using these applications, and the negative effects that may affect him/her and his/ her society because of the exceeding those limits (Sabry, 2003: 11)

- The International Technology Education and technological project for All Americans: it is (the ability of using, managing, evaluating and understanding technology) (ITEA\&TAAP, 2007, p4).

- The researchers define it theoretically as it is (providing the individual with the possible range of knowledge, skills and trends that enable him/ her to properly deal and interact with modern and developed technological applications. In addition, s/he can achieve the maximum benefit for himself/ herself and the community according to the ethical and social limits and awareness of the negative effects that may reflect on him/ her and the society as a result of overcoming those limitations).

- It defines it procedurally as it is (the physics department's teachers possess the minimum knowledge and skills that enable them to understand and apply modern technology in practical life, measured by the degree obtained in the technological enlightenment scale prepared by the paperer for this purpose). 


\section{Productive thinking}

- (Attia 2015): it is a mental process in which the sensory perception interacts with experience and it requires a set of abilities or skills to seek and discover new relationships or unfamiliar methods to achieve a specific goal with internal or external motivations, or both (Attiyah, 2015: 131)

- Theoretical definition:

- It signifies a type of thinking that links the skills of critical thinking and creative thinking. and problem-solving. They are used in order to propose a set of fruitful modern practical ideas that can be used in different life situations.

- Procedural definition: it is a planned process that includes a set of mental skills and includes eight skills (assumptions, interpretation, evaluation, arguments, deduction, conclusion, fluency, flexibility, originality). It also includes the strategies, activities and practical applications that target physics teachers for the purpose of introducing them to productive thinking skills and training them in units. The objective of this process is to raise their motivation towards education and stimulate thinking among their students during the training application period, and it is measured by the degree obtained in the test prepared for this purpose.

Theoretical background: It is necessary to use various educational strategies, and these strategies must be based on the optimal employment of activities and effective educational technology. The trainee's feeling of the importance of training is important and this feeling leads to his/her acceptance of training to get benefit from in order to achieve the goals for which the training program was set (Al-Sakrana, 2011: 19). Training in self-structured learning strategies according to Zimmermann and Bones is a set of plans that help the learner to successfully use cognitive, metacognitive and motivational strategies in addressing and solving academic tasks. Therefore, it is logical for students to possess the important skills for these cognitive and metacognitive strategies, and their possession of them is to be trained because they are applicable to be acquired. 


\section{- $\quad$ Principles of strategy training}

1- Inclusion of students in the evaluation process.

2- Evaluating the changes that occurred in the performance and knowledge of the students' attitudes.

3- Coupling the evaluation process with the learning process.

4- Evaluating the actual use of strategies by students (Salem, Amal, 209: 218217)

The importance of training in the strategies: The principle of self-organized learning is based on the personal freedom. Zimmermann's work emphasizes that the greatest academic successes occur when the students and teachers use the self-organized learning model to guide learning and teaching. By achieving that, it will make the understanding of self-organization for learning an important requirement for both teachers and students. It was designed for this purpose the multi-situations that may face any learner at any stage of learning, and these situations as follows:

1- Quarterly learning: questioning the learner about the method he uses when he remembers the information that was discussed in the chapter on a topic.

2- A homework assignment: the learner is questioned about the way in which he plans to write a specific topic s/he is asked to write

3- An assignment in physics: the learner is questioned about the method for solving a problem in physics or when he faces difficult issues.

4- Self-evaluation in the case of doing homework.

5- Exam performance: the special method for the tests preparing that conducts in the end of course units.

6- Self-evaluation in the case of taking a school test: the method which can obtain the highest amount of correct answers. 
7- Motivation: The method that is used to push and motivate the learner to do the assignment in the presence of circumstances that distract him from studying, that is, shift him/her away from external stimuli of distracting the attention.

8- Home construction, the method that the learner follows in organizing and arranging the place of study and how s/he prepares himself/ herself to write the school assignment.

\section{- Some self-organized learning strategies}

- Self-tasks improvement strategies: (the goal setting and planning strategy, organizing and transferring information, recollection and recall)

- The strategies for improving academic behavior (self-evaluation strategy, self-reward, record-keeping)

- $\quad$ The strategies for improving the learning environment (environmental ranking strategy, seeking information, seeking help, reviewing records (Zimmerman, 1986,33-40)

- The two Researchers have extracted the most important strategic steps after reviewing many sources that suit the sample, and the most important are (Al-Janahi, 2015, Soleimani, 2016, Abdul-Majeed, 2015)

- Technological enlightenment: Through the following chart, we note the relationship of the concept of technological enlightenment with other terms 
Technological enlightenment

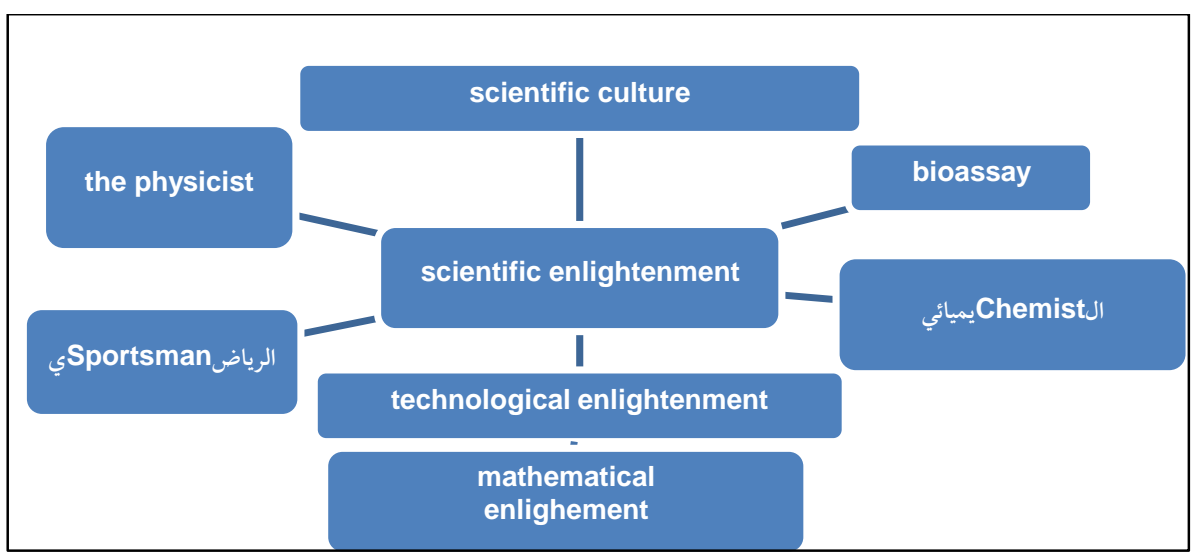

Chart No. (1) The relationship of technological enlightenment to other terms (prepared by the two Researchers)

It is a basis in the work of the technological enlightenment scale that are adopted by the two Researchers.

\section{Areas of technological enlightenment:}

Technological enlightenment programs include a group of areas, the most important are the following:

1- The nature of science and technology: it is to introduce students to the nature of science and technology, as this field includes:

A. The nature of science: There are three views that differ within in determining the nature of science and they are:

- The static view of science. - The Dynamic view of science. - The integrative view of science.

B. The nature of technology: There are several visions of the nature of technology, the most important are:

- $\quad$ Considering technology as an application of science that has its own devices and tools. 
2- The relationship of science in technology: This relationship is emerged in several aspects, the most important are:

- Independence of science and technology. -The overlap of science and technology.

- Integration of science and technology. -Science and technology interaction.

- Science and technology, whichever comes first.

3- The relationship of science and technology with society: it is an interactive and reciprocal relationship, as each is affected by and influenced by the other.

4- The Issues resulting from the interaction of science, technology and society: This field focuses on the problems and issues resulting from the interaction of science, technology and society that have negative effects on the individual and his/her environment locally and globally.

5- The ethics of science and technology: This field includes three basic factors, as follows:

- The ethics of those working in science and technology. -Ethics of science and technology users.

- Settling controversial ethical issues.

6- Modern applications of science and technology: This field includes everything that is modern and innovated from the applications of science and technology in all aspects and fields of human life. (Sabry and Salah, 2005: 49)

The Dimensions of technological enlightenment

1- The Knowledgeable: It includes the information and knowledge that should be provided to the individual regarding the mentioned areas of technological enlightenment which includes facts, concepts, terminology, principles (generalizations), laws and theories. 
2- the Skillful (psychomotor): it includes mental skills such as scientific thinking skills, critical thinking, innovative thinking, and science processes (observation, classification, measurement, inference and expectation, communication, interpretation, etc.). The practical skills are as the skills of dealing with devices, equipment, materials, the skills of using them, maintenance, and the skills of performing some operations (forming, cutting, linking, mixing, measuring, design, etc.).

3- The effective: This dimension includes all the outputs related to the emotional aspect, such as technological awareness, technological sense, and tendencies towards technology.

4- The social: This dimension includes all the experiences that the individual needs to acquire in the areas of technological enlightenment related to the negative and positive effects, results, issues and social changes resulting from science and technology, and the extent of this reflection on customs, traditions and social values.

5- The ethical: If technology ethics is the most important area of technological enlightenment, then the ethical dimension represents one of its most important dimensions, as this dimension focuses on providing students with patterns of ethical behavior in dealing with technological applications. $\mathrm{t}$ also focuses on raising the individual's awareness of ethical issues related to science and technology, and developing his/her ability to understand and analyze the causes, consequences and consequences of those issues by focusing on the stages of decision-making and its procedures.

2- Decision-making: It is considered the most important dimension that affects and is affected by other dimensions. This dimension focuses on qualifying and training the ordinary individual and accord him/her the ability to make decisions, and issuing a correct opinion or judgment when confronting any situation, problem or issue related to science and technology. This process can be summarized in five stages: 
planning, data acquisition, data organization, data synthesis, and decision making. (Sabry, 2005: 95)

Productive thinking: the individual takes to understand reality and make honest judgments about facts and problems via using the mental conduct with the intention of reaching specific goals or treatments. In the sense that, it is an approach of thinking for the purpose of understanding, analyzing and diagnosing on the basis of the causative relationships between its variables. Productive thinking is the type that addresses reality and leads to results with beneficial benefits for the individual and society. So, it is creative generative thinking in reaching prominent results as it is a part of the creative process. One of the prominent features is breaking out of the ordinary and feeling in need since our thinking is still verbal due to a problem in our educational curricula, cultural backgrounds, or ruling systems that have succeeded our nation (Atiyah and AlHashemi, 2015: 131).

\section{- Literature review}

Studies dealing with self-structured learning strategies

\begin{tabular}{|c|c|c|c|c|c|c|c|}
\hline Paperer's & Paperer's & Paperer's & Paperer's & Paperer's & Paperer's & Paperer's & Paperer's \\
\hline Name & Name & Name & Name & Name & Name & Name & Name \\
\hline Country & Country & Country & Country & Country & Country & Country & Country \\
\hline Name & Name & Name & Name & Name & Name & Name & Name \\
\hline Paper Year & Paper Year & Paper Year & Paper Year & Paper Year & Paper Year & Paper Year & Paper Year \\
\hline Stage of & Stage of & Stage of & Stage of & Stage of & Stage of & Stage & Stage \\
\hline Study & Study & Study & Study & Study & Study & Study & Study \\
\hline Sample & Sample & Sample & Sample & Sample & Sample & Sample & Sample \\
\hline Size Paper & Size Paper & Size Paper & Size Paper & Size Paper & Size Paper & Size Paper & Size Paper \\
\hline Tools & Tools Paper & Tools & Tools & Tools & Tools & Tools & Tools \\
\hline Paper & Results & Paper & Paper & Paper & Paper & Paper & Paper \\
\hline Results & & Results & Results & Results & Results & Results & Results \\
\hline
\end{tabular}




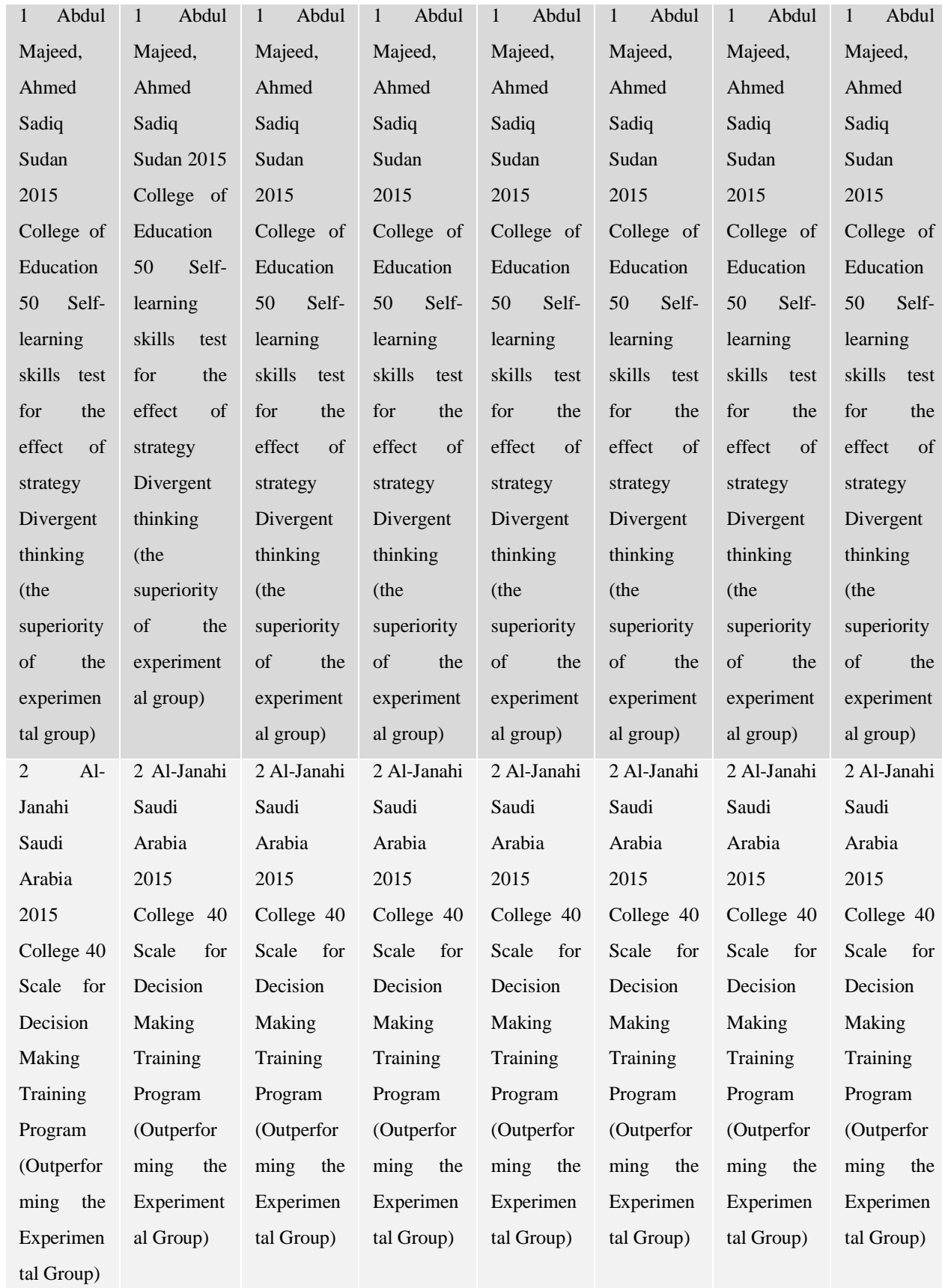




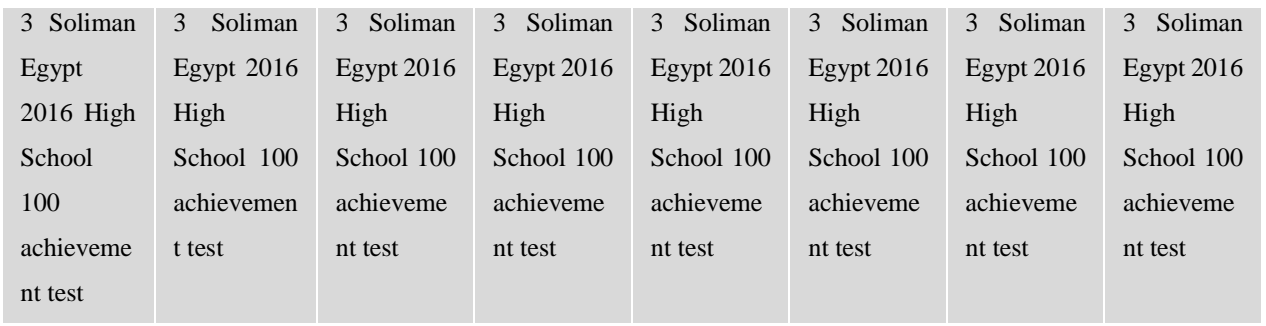

\section{Studies dealing with technological enlightenment}

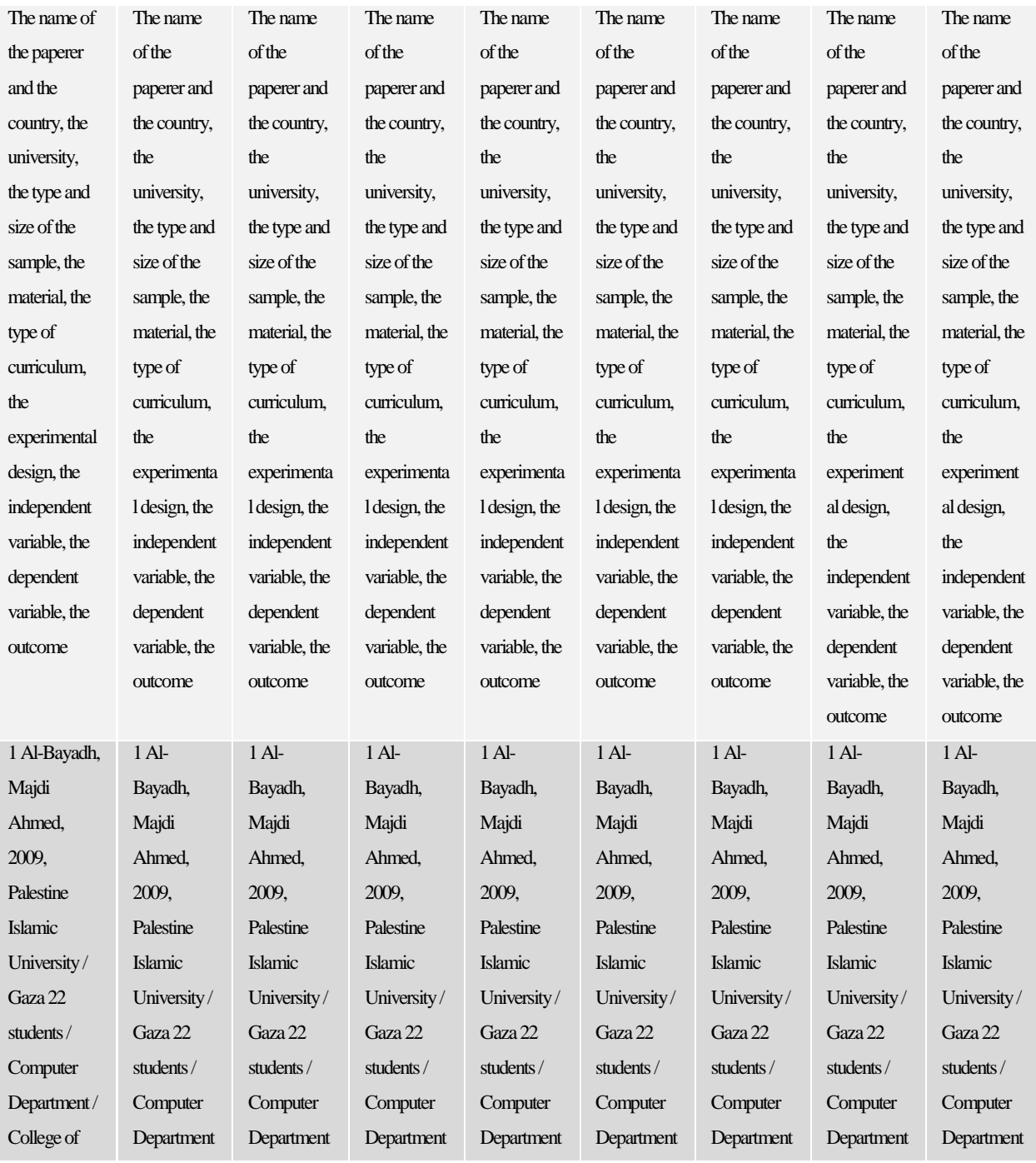




\begin{tabular}{|c|c|c|c|c|c|c|c|c|}
\hline \multirow{5}{*}{$\begin{array}{l}\text { Professional } \\
\text { and Applied } \\
\text { Sciences } \\
\text { Courses of } \\
\text { the }\end{array}$} & /College of & /College of & /College of & /College of & /College of & /College of & /College of & / College of \\
\hline & Professional & Professional & Professional & Professional & Professional & Professional & Professional & Professional \\
\hline & and Applied & and Applied & and Applied & and Applied & and Applied & and Applied & and Applied & and Applied \\
\hline & Sciences & Sciences & Sciences & Sciences & Sciences & Sciences & Sciences & Sciences \\
\hline & Courses of & Courses of & Courses o & Courses of & Courses of & Courses of & Courses of & Courses of \\
\hline Department & the & the & the & the & & th & th & the \\
\hline of & Department & Department & Department & Department & Department & Department & Department & Department \\
\hline Descriptive & of & of & o & of & of & 0 & of & of \\
\hline and & Descriptive & Descriptive & Descriptive & Descriptive & Descriptive & Descriptive & Descriptive & Descriptive \\
\hline Analytical & anc & and & anc & and & & an & an & and \\
\hline Computer & Analytical & Analytical & Analytical & Analytical & Analytical & Analytical & Analytical & Analytical \\
\hline Technologica & Com & Computer & Computer & Computer & Computer & Computer & Computer & Computer \\
\hline 1 & Technologi & Technologic & Technologi & Technologi & Technologi & Technologi & Technologi & Technologi \\
\hline enlightenmen & $\mathrm{cal}$ & al & & & & & & $\mathrm{cal}$ \\
\hline t for students & enlightenme & enlightenme & enlightenme & enlightenme & enlightenme & enlightenme & enlightenm & enlightenm \\
\hline (knowledge & nt for & nt for & nt for & nt for & nt for & nt for & ent for & ent for \\
\hline level, attitude & stuc & stu & stu & stu & stu & st & st & dents \\
\hline and skill) The & (knowledge & (knowledge & (knowledge & (knowledge & (knowledge & (knowledge & wledge & (knowledge \\
\hline higher the & level, & level, & level & level, & level, & leve & leve & leve \\
\hline students & atti & attit & atti & attit & atti & atti & nd & attitude \\
\hline 'grades in the & skill) The & skill) The & skill) The & skill) The & skill) The & skill) The & skill) The & skill) The \\
\hline field of & higher the & higher the & high & high & higher the & higher the & higher the & higher the \\
\hline technology, & students & students & students & students & students & students & students & students \\
\hline networks and & 'grades in & 'grades in & 'grades in & 'grades in & 'grades in & 'grades in & 'grades in & 'grades in \\
\hline electronics & the field of & the field of & the field of & the field of & the field of & the field of & the field of & the field of \\
\hline the more this & technology, & technology, & technology, & technology, & technology, & technology, & technology, & technology, \\
\hline leads To & networks & networks & networks & networks & networks & networks & networks & networks \\
\hline increase the & and & and & anc & and & anc & an & an & ar \\
\hline level of & electronics & electronics & electronics & electronics & electronics & electronics & electronics & electronics \\
\hline technological & the more & the more & the more & the more & the more & the & the more & the more \\
\hline enlightenmen & this leads & this leads To & this leads & this leads & this leads & eads & this leads & lead \\
\hline t of the & To increase & increase the & To increase & To increase & To increase & To increase & To increase & To increase \\
\hline students and & the level of & level of & the level of & the level of & the level of & the level of & the level of & the level of \\
\hline vice versa & technologic & technologic & technologic & technologic & technologic & technologic & technologic & technologic \\
\hline & al & & & & & & & al \\
\hline & enlightenme & enlightenme & enlightenme & enlightenme & enlightenme & enlightenme & enlightenm & enlightenm \\
\hline & nt of the & nt of the & nt of the & nt of the & nt of the & nt of the & ent of the & ent of the \\
\hline & students and & students and & students and & students and & students and & students and & students and & students and \\
\hline & & & & vice & vesa & vice versa & sa & ersa \\
\hline
\end{tabular}




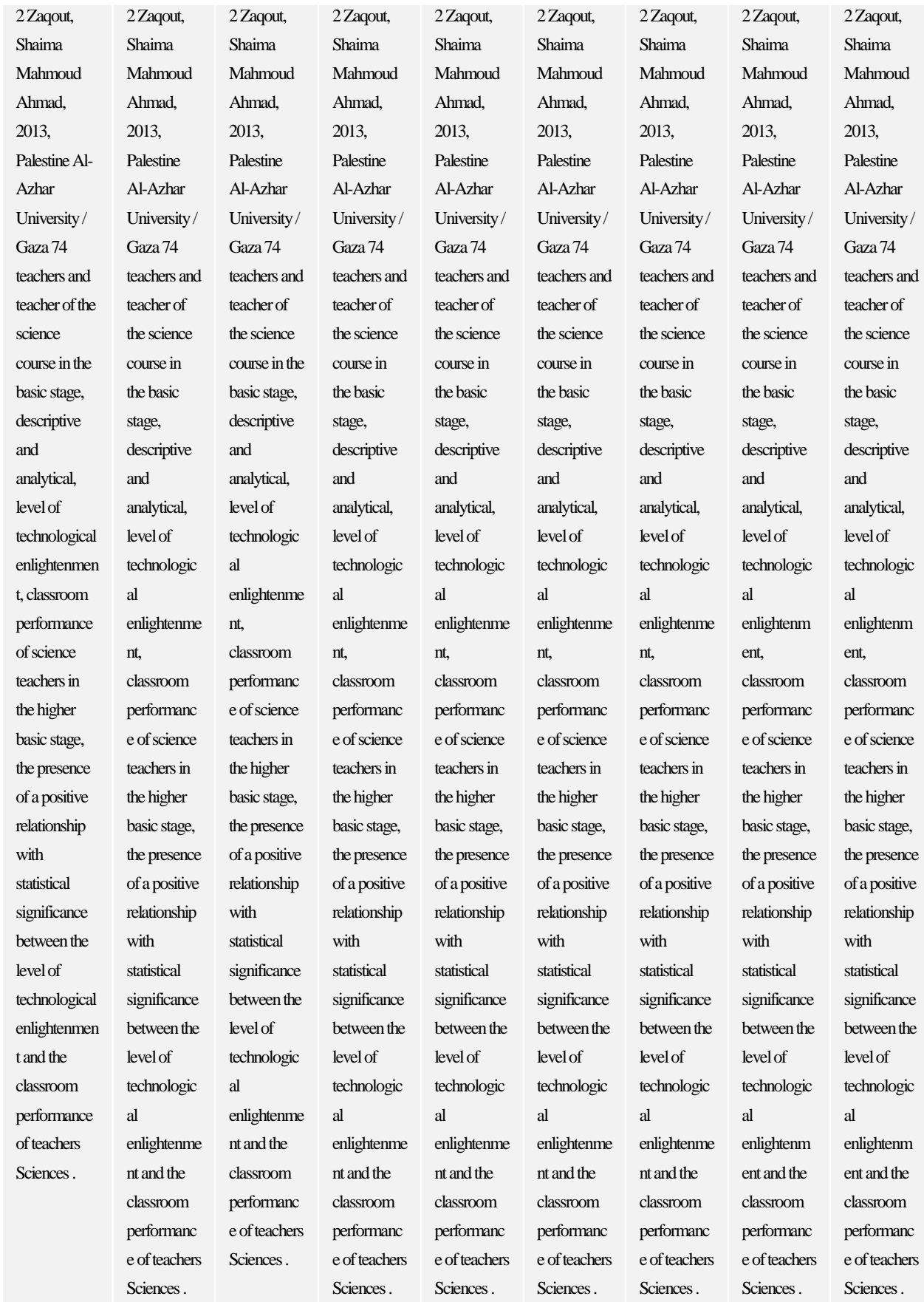




\begin{tabular}{|c|c|c|c|c|c|c|c|c|}
\hline 3 & 3 & 3 & 3 & 3 & 3 & 3 & 3 & 3 \\
\hline Muhammad, & Muhamma & Muhamma & Muhamma & Muhamma & Muhamma & Muhamma & Muhamma & Muhamma \\
\hline Afrah & d, Afrah & d, Afrah & d, Afrah & d, Afrah & d, Afrah & d, Afrah & d, Afrah & d, Afrah \\
\hline Yassin, 2015, & Yassin, & Yassin, & Yassin, & Yassin, & Yassin, & Yassin, & Yassin, & Yassin, \\
\hline Iraq, & 2015, Iraq, & 2015, Iraq, & 2015, Iraq, & 2015, Iraq, & 2015, Iraq, & 2015, Iraq, & 2015, Iraq, & 2015, Iraq, \\
\hline University of & University & University & University & University & University & University & University & University \\
\hline Baghdad & of Baghdad & of Baghdad & of Baghdad & of Baghdad & of Baghdad & of Baghdad & of Baghdad & of Baghdad \\
\hline
\end{tabular}

\section{Studies have dealt with productive thinking}

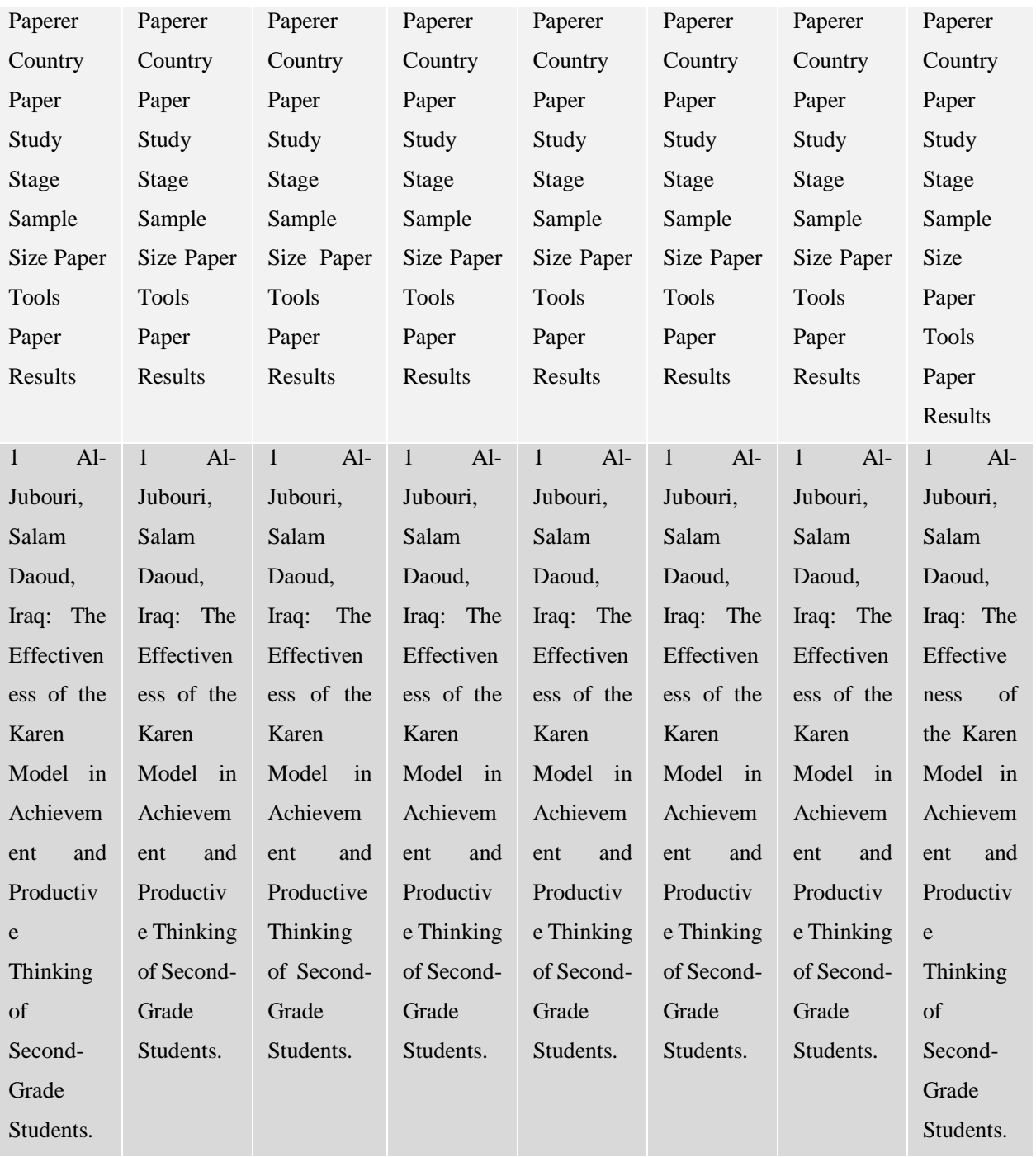




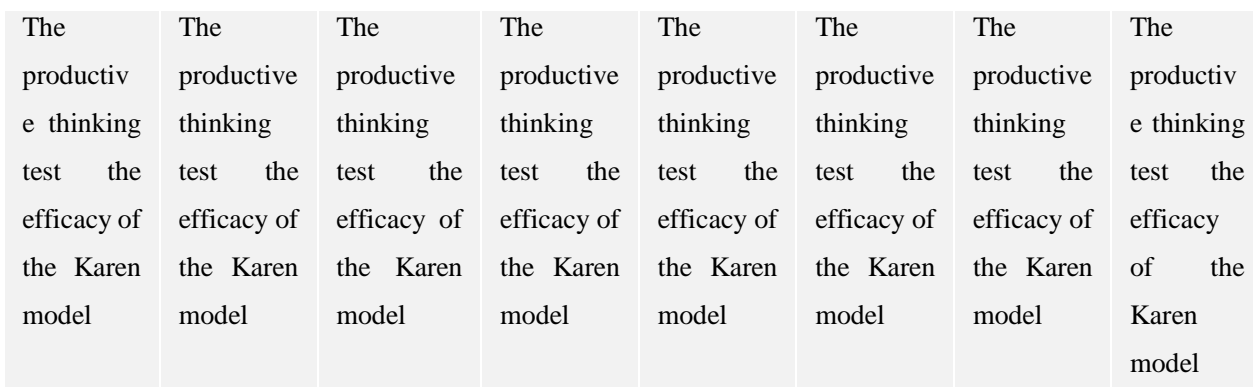

\section{Procedures}

- Designing the training program after observing a set of program designs by the Researchers and they did not find a design for teacher training that fits with the objectives according to their knowledge. Therefore, the training program was designed and consists of three stages:

- $\quad$ The planning stages

- Implementation stage

- The evaluation of the program stage

Furthermore, the semi-hermetic experimental design test is chosen, with the experimental and control groups of a post-test of the productive thinking for physics teachers in Table (1)

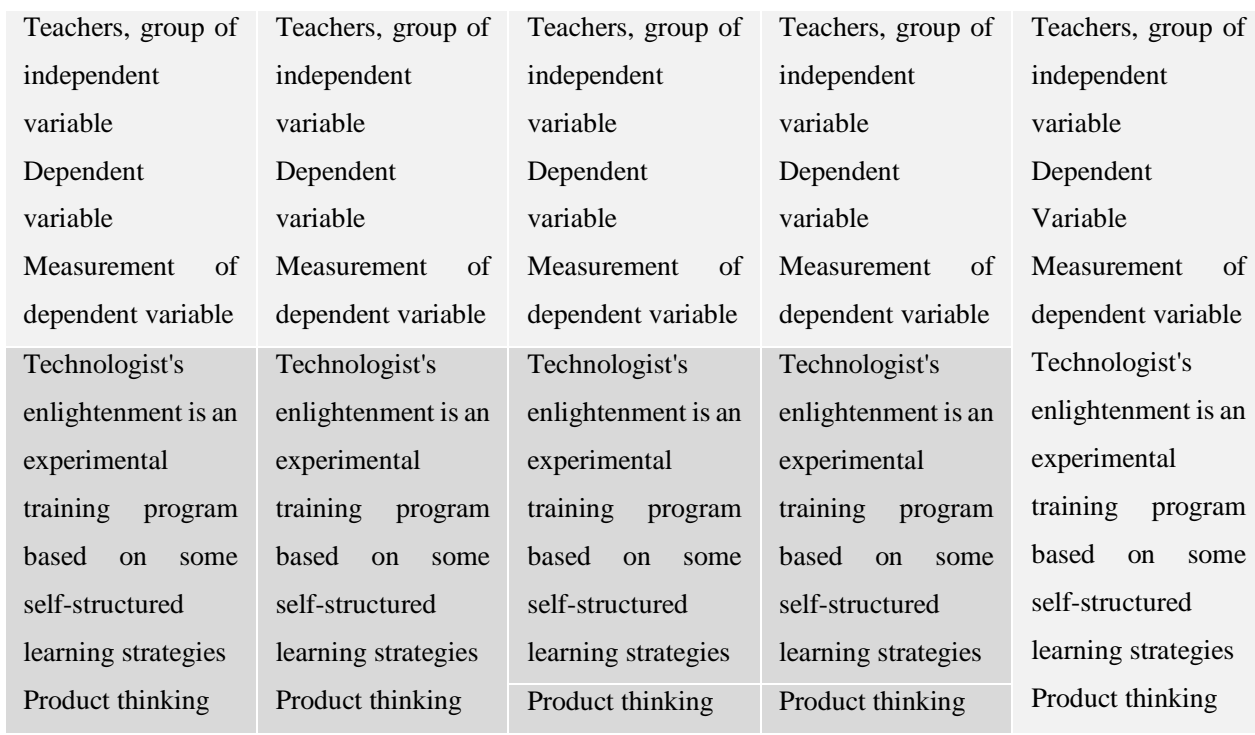


- The sample: The sample was chosen for the experimental group of physics teachers. The number of teachers reached (16) who had the desire as well as their volunteering to participate in the training program. Concerning the remaining number which is (16) teachers who are considered as a controlled group that is not subject to the training program for the school year (20192020).

General characteristics: For the purpose of fixing information about the two groups, the two Researchers distributed a questionnaire to determine the characteristics of the trainees, and after collecting the information, they find the following:

- Male and female trainees.

- All trainees are graduated from the Faculties of Education.

- All trainees have an experience of teaching nearly (4-13).

- All trainees have the degree of College of Education / Department of Physics.

- All samples have not previously participated in a program similar to this prepared training program.

- $\quad$-All teachers have experience in using computers.

- Technological enlightenment scale prior to $1 / 10 / 2019$ on the teaching community.

Table (2) Mann and Tenny value of experimental control group scores for Technological Enlightenment Scale

\begin{tabular}{|c|c|c|c|c|c|}
\hline $\begin{array}{l}\text { Group The } \\
\text { number }\end{array}$ & $\begin{array}{l}\text { Group The } \\
\text { number }\end{array}$ & $\begin{array}{l}\text { Group The } \\
\text { number }\end{array}$ & $\begin{array}{l}\text { Group The } \\
\text { number }\end{array}$ & $\begin{array}{l}\text { Group The } \\
\text { number }\end{array}$ & $\begin{array}{l}\text { Group The } \\
\text { number }\end{array}$ \\
\hline Average ranks & Average ranks & Average ranks & Average ranks & Average ranks & Average ranks \\
\hline ranks & Total ranks & Total & Total & Total & Total \\
\hline The computed & The computed & The computed & The computed & The computed & The computed \\
\hline $\begin{array}{l}\text { U value The } \\
\text { tabular } \\
\text { value }\end{array}$ & $\begin{array}{l}\mathrm{U} \text { value The } \\
\text { tabular } \mathrm{U} \\
\text { value }\end{array}$ & $\begin{array}{l}\mathrm{U} \text { value The } \\
\text { tabular } \mathrm{U} \\
\text { value }\end{array}$ & $\begin{array}{l}\mathrm{U} \text { value The } \\
\text { tabular } \mathrm{U} \\
\text { value }\end{array}$ & $\begin{array}{l}\mathrm{U} \text { value The } \\
\text { tabular } \mathrm{U} \\
\text { value }\end{array}$ & $\begin{array}{l}\mathrm{U} \text { value The } \\
\text { tabular } \mathrm{U} \\
\text { value }\end{array}$ \\
\hline \multirow[t]{2}{*}{$\begin{array}{l}\text { Experimental } \\
1614,44231 \\
9564\end{array}$} & \multirow[t]{2}{*}{$\begin{array}{l}\text { Experimental } \\
1614,44231 \\
9564\end{array}$} & $\begin{array}{l}\text { Experimental } \\
1614,44231 \\
9564\end{array}$ & $\begin{array}{l}\text { Experimental } \\
1614,44231 \\
9564\end{array}$ & $\begin{array}{l}\text { Experimental } \\
1614,44231 \\
9564\end{array}$ & $\begin{array}{l}\text { Experimental } \\
1614,44231 \\
9564\end{array}$ \\
\hline & & $\begin{array}{ll}\text { Control } & 16 \\
18,56297 & \end{array}$ & $\begin{array}{ll}\text { Control } & 16 \\
18,56297 & \end{array}$ & $\begin{array}{ll}\text { Control } & 16 \\
18,56297 & \end{array}$ & $\begin{array}{ll}\text { Control } & 16 \\
18,56297 & \end{array}$ \\
\hline
\end{tabular}


The test of pre-productive thinking

Table (3) Mann Whitney's value for experimental and control group scores for the productive thinking test

\begin{tabular}{|c|c|c|c|c|c|}
\hline $\begin{array}{l}\text { Group The } \\
\text { number }\end{array}$ & $\begin{array}{l}\text { Group The } \\
\text { number }\end{array}$ & $\begin{array}{l}\text { Group The } \\
\text { number }\end{array}$ & $\begin{array}{l}\text { Group The } \\
\text { number }\end{array}$ & $\begin{array}{l}\text { Group The } \\
\text { number }\end{array}$ & $\begin{array}{l}\text { Group The } \\
\text { number }\end{array}$ \\
\hline Average ranks & Average ranks & Average ranks & Average ranks & Average ranks & Average ranks \\
\hline Total ranks & Total ranks & Total ranks & Total ranks & Total ranks & Total ranks \\
\hline The computed & The computed & The computed & The computed & The computed & The computed \\
\hline U value The & $\mathrm{U}$ value The & $\mathrm{U}$ value The & U value The & $\mathrm{U}$ value The & $\mathrm{U}$ value The \\
\hline $\begin{array}{l}\text { tabular } \mathrm{U} \\
\text { value }\end{array}$ & $\begin{array}{l}\text { tabular } \\
\text { value }\end{array}$ & $\begin{array}{l}\text { tabular } \\
\text { value }\end{array}$ & $\begin{array}{l}\text { tabular } \\
\text { value }\end{array}$ & $\begin{array}{l}\text { tabular } \\
\text { value }\end{array}$ & $\begin{array}{l}\text { tabular } \\
\text { value }\end{array}$ \\
\hline Experimental & Experimental & Experimental & Experimental & Experimental & Experimental \\
\hline 15,70 & 15,70 & 15,70 & 15,70 & 15,70 & 15,70 \\
\hline \multirow{3}{*}{$\begin{array}{l}235,50115,50 \\
47\end{array}$} & $235,50115,50$ & $235,50 \quad 115,50$ & $235,50115,50$ & $235,50115,50$ & $235,50115,50$ \\
\hline & 47 & 47 & 47 & 47 & 47 \\
\hline & & $\begin{array}{l}\text { Control } 16 \\
16,21292,50\end{array}$ & $\begin{array}{l}\text { Control } 16 \\
16,21292,50\end{array}$ & $\begin{array}{l}\text { Control } 16 \\
16,21292,50\end{array}$ & $\begin{array}{l}\text { Control } 16 \\
16,21292,50\end{array}$ \\
\hline
\end{tabular}

Trainers: The two Researchers prepared the requirements for the training process and carried out the training on their own.

Constructing a training program: After reviewing the literature and previous studies that dealt with preparing training programs for the teacher, including the study (Al-Shahrani, 2013) (Al-Janahi, 2015), after that the stages of the training programs were determined.

1- Analysis stage.

2- The design stage.

3- Evaluation stage. 
Table (4) sessions of the training program

\begin{tabular}{|c|c|c|c|}
\hline $\begin{array}{l}\text { ay and date session } \\
\text { rogram Vocabulary } \\
\text { raining Methods }\end{array}$ & $\begin{array}{l}\text { ay and date session } \\
\text { rogram Vocabulary } \\
\text { raining Methods }\end{array}$ & $\begin{array}{l}\text { ay and date session } \\
\text { rogram Vocabulary } \\
\text { raining Methods }\end{array}$ & $\begin{array}{l}\text { ay and date session } \\
\text { rogram Vocabulary } \\
\text { raining Methods }\end{array}$ \\
\hline first & first & rst & first \\
\hline $\begin{array}{l}\text { Second: Definitions and } \\
\text { program delivery } \\
\text { Training on the } \\
\text { Telegram program }\end{array}$ & $\begin{array}{l}\text { econd: Definitions and } \\
\text { rogram delivery } \\
\text { raining on the } \\
\text { 'elegram program }\end{array}$ & $\begin{array}{l}\text { econd: Definitions and } \\
\text { rogram delivery } \\
\text { raining on the } \\
\text { elegram program }\end{array}$ & $\begin{array}{l}\text { Second: Definitions and } \\
\text { program delivery } \\
\text { Training on the } \\
\text { Telegram program }\end{array}$ \\
\hline $\begin{array}{l}\text { The first unit: teacher } \\
\text { cooperating groups, } \\
\text { discussion, } \\
\text { brainstorming, short } \\
\text { lecture }\end{array}$ & $\begin{array}{l}\text { The first unit: teacher } \\
\text { cooperating groups, } \\
\text { discussion, } \\
\text { brainstorming, short } \\
\text { lecture }\end{array}$ & $\begin{array}{l}\text { The first unit: teacher } \\
\text { cooperating groups, } \\
\text { discussion, } \\
\text { brainstorming, short } \\
\text { lecture }\end{array}$ & $\begin{array}{l}\text { The first unit: teacher } \\
\text { cooperating groups, } \\
\text { discussion, } \\
\text { brainstorming, short } \\
\text { lecture }\end{array}$ \\
\hline 101010 & 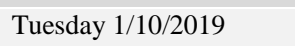 & 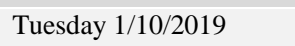 & \\
\hline $\begin{array}{l}\text { unday } 6 / 10 / 2019 \text { the } \\
\text { inth }\end{array}$ & nth & nth & nth \\
\hline $\begin{array}{l}\text { The eighth session five: } \\
\text { planning strategies for } \\
\text { self-organized } \\
\text { education, } \\
\text { brainstorming, } \\
\text { cooperative learning, } \\
\text { and explanatory } \\
\text { presentations }\end{array}$ & $\begin{array}{l}\text { The eighth session five: } \\
\text { planning strategies for } \\
\text { self-organized } \\
\text { education, } \\
\text { brainstorming, } \\
\text { cooperative learning, } \\
\text { and explanatory } \\
\text { presentations }\end{array}$ & $\begin{array}{l}\text { The eighth session five: } \\
\text { planning strategies for } \\
\text { self-organized } \\
\text { education, } \\
\text { brainstorming, } \\
\text { cooperative learning, } \\
\text { and explanatory } \\
\text { presentations }\end{array}$ & $\begin{array}{l}\text { The eighth session five: } \\
\text { planning strategies for } \\
\text { self-organized } \\
\text { education, } \\
\text { brainstorming, } \\
\text { cooperative learning, } \\
\text { and explanatory } \\
\text { presentations }\end{array}$ \\
\hline $\begin{array}{l}\text { Ionday 7/10/2019 } \\
\text { leven }\end{array}$ & $\begin{array}{l}\text { Monday 7/10/2019 } \\
\text { Eleven }\end{array}$ & $\begin{array}{l}\text { Monday 7/10/2019 } \\
\text { Eleven }\end{array}$ & Monday 7/10/2019 \\
\hline $\begin{array}{l}\text { Wednesday } 9 / 10 / 2019 \\
\text { the fifteenth }\end{array}$ & $\begin{array}{l}\text { Wednesday } 9 / 10 / 2019 \\
\text { the fifteenth }\end{array}$ & $\begin{array}{l}\text { Wednesday 9/10/2019 } \\
\text { the fifteenth }\end{array}$ & $\begin{array}{l}\text { Wednesday 9/10/2019 } \\
\text { the fifteenth }\end{array}$ \\
\hline $\begin{array}{l}\text { The sixteenth, the eighth } \\
\text { unit: evaluation of the } \\
\text { teaching of cooperative } \\
\text { group strategies, } \\
\text { discussion, } \\
\text { brainstorming }\end{array}$ & $\begin{array}{l}\text { The sixteenth, the eighth } \\
\text { unit: evaluation of the } \\
\text { teaching of cooperative } \\
\text { group strategies, } \\
\text { discussion, } \\
\text { brainstorming }\end{array}$ & $\begin{array}{l}\text { The sixteenth, the eighth } \\
\text { unit: evaluation of the } \\
\text { teaching of cooperative } \\
\text { group strategies, } \\
\text { discussion, } \\
\text { brainstorming }\end{array}$ & $\begin{array}{l}\text { The sixteenth, the eighth } \\
\text { unit: evaluation of the } \\
\text { teaching of cooperative } \\
\text { group strategies, } \\
\text { discussion, } \\
\text { brainstorming }\end{array}$ \\
\hline $\begin{array}{l}\text { Thursday } 10 / 10 / 2019 \\
\text { the seventeenth }\end{array}$ & $\begin{array}{l}\text { Thursday } 10 / 10 / 2019 \\
\text { the seventeenth }\end{array}$ & $\begin{array}{l}\text { Thursday } 10 / 10 / 2019 \\
\text { the seventeenth }\end{array}$ & $\begin{array}{l}\text { Thursday } 10 / 10 / 2019 \\
\text { the seventeenth }\end{array}$ \\
\hline
\end{tabular}




\begin{tabular}{l|l|l|l|}
$\begin{array}{l}\text { The eighteenth, the } \\
\begin{array}{l}\text { ninth unit: assessment } \\
\text { tools, cooperative group, }\end{array}\end{array}$ & $\begin{array}{l}\text { The eighteenth, the } \\
\text { ninth unit: assessment }\end{array}$ & $\begin{array}{l}\text { The eighteenth, the } \\
\text { ninth unit: assessment }\end{array}$ & The eighteenth, the \\
ninth unit: assessment
\end{tabular}

\section{search instrument:}

Technological Enlightenment Scale: After the Researchers acquainted themselves with the literature and studies conducted in this field, the two Researchers adopted the scale prepared by (Faiz Salem Abd, 2016) with the following criteria (nature of technology, technology and society, design, capabilities of the technological scientist and the designer world (technological systems) which consists of (60) item.

- The validity of the apparent scale: The two Researchers adopted the percentage of agreement (80\%) or more, as a criterion for the validity of the scale items and the accuracy of their distribution between the fields to which they belong. Moreover, its relevance is to measure the characteristic for which they were set. According to the answers of the judges, some items are amended without dropping any item.

- Construct validity: After calculating the Pearson correlation coefficients among the survey sample scores for each item, their total score on the scale and the degree of the field to which they belong, it becomes clear that all the items are acceptable and statistically significant, thus, the scale has, internal consistency, verified the validity of the structure.

- Exploratory application of the scale: The two Researchers tested an exploratory sample consisting of (35) teachers of the Department of and from the results of correcting and organizing the answers, and then the psychometric properties of the scale were determined:

1- Discriminatory strength of the item: The discriminatory power was extracted and they were all statistically significant because their value is higher than the tabular value of (2.00) at the degree of freedom (59) and 
the level of significance (0.05). Thus, all the scale items were considered distinct.

2- Stability of the scale: The Alpha-Cronbach coefficient of stability was determined, as the reliability coefficient reached (0.727) and this is an acceptable value.

The Productive Thinking Test: The two Researchers prepared the test after reviewing the literature that dealt with productive thinking which is divided into two areas: the field of critical thinking, and it consists of (15) items divided into five skills, for each skill 3 positions. The field of creative thinking which consists of 9 positions distributed on three skills, for each skill 3 items. Table (5)

\begin{tabular}{|c|c|c|}
\hline $\begin{array}{l}\text { Type of thinking Thinking skills } \\
\text { Number of situations }\end{array}$ & $\begin{array}{l}\text { Type of thinking Thinking skills } \\
\text { Number of situations }\end{array}$ & $\begin{array}{l}\text { Type of thinking Thinking skills } \\
\text { Number of situations }\end{array}$ \\
\hline & & Critical Thinking Assumptions 3 \\
\hline Critical Thinking Assumptions 3 & Critical Thinking Assumptions 3 & Interpretation 3 \\
\hline Interpretation 3 & Interpretation 3 & Arguments Evaluation 3 \\
\hline Arguments Evaluation 3 & Arguments Evaluation 3 & \\
\hline Deduction 3 & Deduction 3 & Deduction 3 \\
\hline Conclusion 3 & Conclusion 3 & Conclusion 3 \\
\hline Creative thinking fluency 3 & Creative thinking fluency 3 & Creative thinking fluency 3 \\
\hline Flexibility 3 & Flexibility 3 & Flexibility 3 \\
\hline
\end{tabular}

* Apparent honesty: The test was presented to a group of arbitrators without their opinions about the validity of the test, and an agreement percentage of no less than $(85 \%)$ was approved.

- Construct validity (internal consistency): Constructive validity indicators were checked for each domain. That is by calculating the correlation coefficient for each paragraph of the test by the degree of the critical thinking field using the Pearson equation, as the correlation coefficient ranged between each field of assumptions is (0.680-0.509) and the interpretation (0.676-0.428). Introspection is (0.691-0.431), and the reviews and counseling (0.767-0.257). The arguments evaluation (0.6668-0.363) for reflection on creative thinking 
fluency $(0,396)$, flexibility $(0,458)$, originality $(0,578)$, spatiality $(5,220)$ at the level $(0,05)$ and a score of 58 in all subjects are acceptable.

- The validity of the construction of productive thinking: Through finding the correlation coefficient of each of the test items with the total score of the test productive thinking, which ranged between $(0,242-0,763)$ and compared to the tabular value $(5,220)$ at the level of significance $(0.05)$ and with a degree of freedom (58) are found acceptable.

\section{Product thinking test application}

- The first exploratory sample: the test was applied consisting of (35) teachers and was chosen randomly, and the time spent in applying the test was (50) minutes. The two Researchers supervised that, and the upper and lower groups were taken, and the number of scores in each group reached 27. To find the psychometric characteristics of the test items as follows:

- $\quad$-Difficulty coefficient for the test items: After the correction, the percentage of those who answered the paragraphs with a correct answer is calculated, and a coefficient ranges from (0.32-0.55) as the test is good.

- $\quad$-Distinguishing the test items: After correcting the answers ranged between $(0,38-0,60)$ and thus all the items are considered good.

- Stability: means that the results shown by the test are stable, that is, they give the same results if they are re-applied to the same sample in the same circumstances after an appropriate period of time. $(0,88)$. It is a good reliability coefficient.

- Product thinking test application

\section{The results}

The first null hypothesis: To verify the significance of the differences, the Researchers adopted, so the calculated value of $U$ was (50), which is less than the tabular $\mathrm{U}$ value (70) at the level of significance (0.05) as in Table (6). 
Mann and Tenny value of experimental control group scores on the Technological Enlightenment Scale

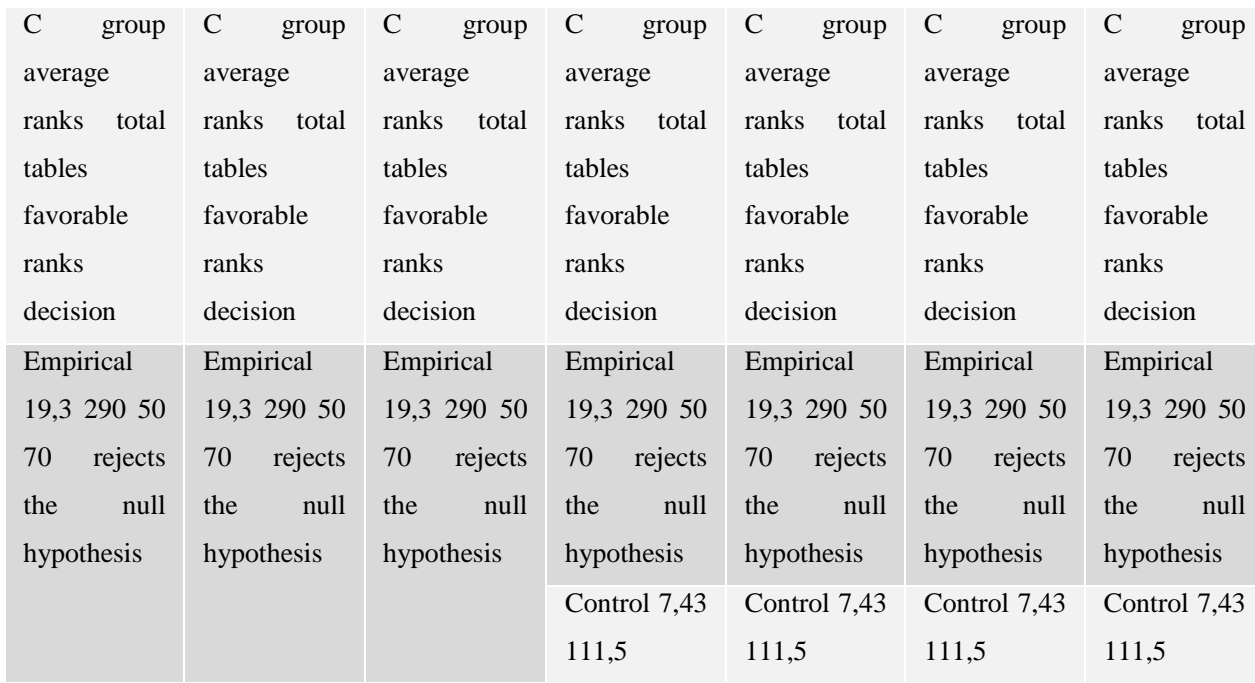

This indicates the existence of a significant difference between the moderate scores of the two groups on the technological enlightenment scale in favor of the experimental group trained according to the training program based on self-organized education strategies.

The second null hypothesis: To verify the significance of the differences, the paperer adopted, so the calculated value of $U$ was (35), which is less than the tabular $U$ value (70) at the level of significance (0.05) as in Table (7)

Mann and Tenny value of experimental control group scores on the productive thinking test.

\begin{tabular}{|c|c|c|c|c|c|c|}
\hline C Group & C Group & C Group & C Group & Group & C Group & Group \\
\hline Average & Average & Average & Average & Average & Average & Average \\
\hline $\begin{array}{l}\text { ranks The } \\
\text { sum of the } \\
\text { taboo ranks }\end{array}$ & $\begin{array}{l}\text { ranks The } \\
\text { sum of the } \\
\text { taboo ranks }\end{array}$ & $\begin{array}{l}\text { ranks The } \\
\text { sum of the } \\
\text { taboo ranks }\end{array}$ & $\begin{array}{l}\text { ranks The } \\
\text { sum of the } \\
\text { taboo ranks }\end{array}$ & $\begin{array}{l}\text { ranks The } \\
\text { sum of the } \\
\text { taboo ranks }\end{array}$ & $\begin{array}{l}\text { ranks The } \\
\text { sum of the } \\
\text { taboo ranks }\end{array}$ & $\begin{array}{l}\text { ranks The } \\
\text { sum of the } \\
\text { taboo ranks }\end{array}$ \\
\hline $\begin{array}{l}\text { the } \\
\text { decision }\end{array}$ & $\begin{array}{l}\text { the } \\
\text { decision }\end{array}$ & $\begin{array}{l}\text { the } \\
\text { decision }\end{array}$ & $\begin{array}{l}\text { the } \\
\text { decision }\end{array}$ & $\begin{array}{l}\text { the } \\
\text { decision }\end{array}$ & $\begin{array}{l}\text { the } \\
\text { decision }\end{array}$ & $\begin{array}{l}\text { the } \\
\text { decision }\end{array}$ \\
\hline
\end{tabular}


This indicates the existence of a significant difference between the moderate scores of the two groups on the productive thinking test in favor of the experimental group trained according to the training program based on self-organized learning strategies.

- Interpretation of the results of technological enlightenment:

In light of the results, it is found that the level of technological enlightenment of physics teachers participating in the training program based on some of the strategies of the self-organized scientist has changed positively than it was before the training. So, this is clear evidence of the impact of the training program that led to a positive change in the level of technological enlightenment of physics teachers towards the use of technology in general, and e-learning in the virtual laboratories in particular, which include many the technological skills that they were ignorant of.

Rather, most of them were fearful and hesitant and did not know how to use this technology or employ it in teaching physics. In addition, their participation in the training program and acquainting them with the advantages of this technology and its software had the effect of removing their fear and employing this technology in teaching. This technology prompted them to make an effective effort in using it and their desire to apply it. In teaching physics even inside the classroom, this is consistent with what was confirmed (Yaqoub: 1989) that "training teachers and providing them with knowledge and experience is an important and influential factor in achieving the goals pursued by training during the training sessions included in the training program (Yaqoub 1989: 330). With the results of many studies such as (Al-Mousawi 2012) and (Muhammad 2015) and it was confirmed by (Al-Ghazal 2015), which showed the positive impact that trained teachers and users of e-learning have on the academic achievement of their students, as well as that the exchange of experiences between the trainees during and after the program has an impact on developing their knowledge and experience. Accordingly, it raises the level of their software production as well as their use of all these matters positively reflected on the outcomes of the training process. 
Interpretation of results: The results related to the second null hypothesis resulted in the superiority of the teachers of the experimental group that had undergone the training program over the teachers of the control group that had not undergone any training program in the test of productive thinking. After performing the test prepared for this purpose, the result can be attributed to the effect of the training program that was prepared according to the self-organized learning strategies because of the comprehensiveness, accuracy and objectivity they describe. The inputs in the analysis stage of the approved training program contributed to identifying the strengths and weaknesses, as well as identifying the characteristics of the trainees and identifying their needs in defining the objectives of the training program. As the content of the training program, represented by the information, skills and activities to be communicated to the trainees, has been determined, the progression in the topics and the permissible period of time, and the organization of content, activities, means and models that help trainees gain experience after consulting the opinions of teachers in light of the vocabulary of the training program. This result gets an agreement with the results of both the study (Al-Janahi, 2015), the study (Al-Jubouri 2017), and the study (Soliman, 2016) on the impact of building training programs through building and organizing appropriate content.

It also refers to the preparing various teaching methods to suit the content of the training program with the type of training, teaching, the appropriate means and activities. Furthermore, the testing evaluation methods are to improve their course during training and the final evaluation to ensure the achievement of the desired goals and the adoption of structured feedback to modify and improve the performance of trainees. 


\section{Conclusions:}

\section{In light of the results:}

1. The positive effect of the training program based on some self-organized learning strategies through the change in the level of technological enlightenment of the physics teachers, the sample.

2. The positive impact of using some self-organized learning strategies by the teachers who underwent the training program in the increasing their technological enlightenment and productive thinking compared to those who did not undergo the training.

\section{Recommendations}

1- Applying the training program to students who applied their learning in colleges.

2- Reducing the heavy burden on physics teachers to reduce the fear of this subject and to increase the efficiency of teaching and learning.

1- 3-The educational institutions should commence to set the development of educational policies and strategies that stem from the needs of the age and keep pace with the wheel of scientific and technical development. It should also adopt setting educational and technological plans to benefit from scientific transformations in comprehensive human development projects. By adopting the modern educational strategies such as a self-organized learning strategy to achieve meaningful learning and develop interaction skills and self-reliance

3- Holding and organizing seminars and training workshops for science teachers to employ electronic learning media in teaching science in virtual learning environments as a technology innovator. Emphasizing the need for educational leaders to pay attention to introducing the e-learning method in all educational stages, especially the use of computers and internet in science education.

4- The curricula with the activities and experiments that employ the virtual learning environments in the educational process, especially in the levels of 
application, analysis, evaluation, and teaching students of the college of education should involve the special courses in the use of tools and applications of virtual education technology.

5- The Ministries of Education and Higher Education and Scientific Paper should take the initiative role to develop systems and legislations and prepare intensive awareness programs to spread computer culture in society. Then, they should set a comprehensive and clear-cut policy as a center for sustainable development of technological information literacy and directing students towards e-learning.

6- Preparing comprehensive programs that develop the level of technological enlightenment and productive thinking by providing bulletins to students and parents about the importance of technological enlightenment in various fields. It should also show its usefulness to society in order to change the orientations of teachers and students about technological courses and to work on setting the standards for designing and evaluating the electronic learning means.

7- Constructing and developing communication and information infrastructures by providing informational means of computers, electronics, software and experts in the field of dealing with information. It also works to hold the agreements with international universities of the developed countries to get benefits from their expertise in the field of technology and engage them to contribute in the development of educational programs in our Iraqi universities. The benefits from the experiences of developed countries can merge them to conform with the determinants of different societies to suit the customs, traditions and surrounding environment.

8- The contribution should increase the promotion, encouragement of scientific paper, development efforts, and do and studies on the use of organized learning environments and the productive thinking at other stages of life. 


\section{Suggestions:}

1. The effectiveness of training physics teachers according to self-organized learning strategies and according to the technology program and their productive thinking on their teaching performance.

2. The effect of training physics teachers according to technology programs on their skills for designing and preparing the computerized educational programs.

3. Conducting a similar study in teaching practical experiences of the other subjects in other scientific departments.

4. Conducting a study similar in teaching physics at the secondary schools. 


\section{References}

Abdul-Majeed, Ahmed Sadiq, 2015: The Impact of Divergent Thinking Strategies in Teaching Calculus on Self-Structured Learning Skills and Appreciation of Mathematical Values among Teachers' Students at the College of Education Educational Journal, No. 117, Volume 3, College of Education in its son, King Khalid University.

Al-Bayadh, Muhammad Ahmad, (2009): (The level of technological enlightenment among students of the Computer Department of the Society of Professional and Applied Sciences) Master Thesis, Islamic University, Gaza / Palestine

Al-Fawzan, Fawzan Abdul-Rahman Hamad, 2008: Self-organized learning strategies and their relationship to thinking styles among students of King Fahd University of Petroleum and Minerals, a predictive study, an unpublished master's thesis, College of Graduate Studies, Gulf University, Saudi Arabia.

Al-Ghazal, Mai Muhammad Mahmoud, (2015): (The effectiveness of using interactive simulations based on self-learning in developing chemical concepts and some visual thinking skills among high school students), unpublished master's thesis, Suez Canal University / College of Education in Al-Arish / Cairo.

Al-Janahi, Maymun bint Salman bin Muhammad, 2015: The effectiveness of a training program in developing some self-organized learning strategies and its impact on the decision-making skills of female students of the College of Education, Qassim University, an unpublished master's thesis, College of Education / Qassim University.

Al-Jubouri, Salam Daoud, 2017: The Effectiveness of the Karen Model in Achievement and Productive Thinking of Second-Grade Intermediate Students in Physics, Master Thesis, Al-Qadisiyah University, College of Education 
Al-Mousawi, Mohsen Taher (2008): (The effect of two cooperative learning strategies on practical and theoretical performance among students of the Physics Department - College of Education) Unpublished Master Thesis University of Baghdad / College of Education / Ibn Al-Haytham

Al-Mousawi, Mohsen Taher. (2012). The impact of the computerized program (EWB) based on modeling, simulation and skill course strategy in theoretical and practical performance and the development of metacognitive skills among students of the Physics Department), unpublished $\mathrm{PhD}$ thesis at Baghdad University / College of Education / Ibn Al Haytham.

Al-Sakraneh, Bilal Khalaf (2011): Recent trends in training, Dar Al-Masirah, Amman, Jordan.

Al-Shahrani: Fahd Yahya Ali: 2013: A proposed training program to develop training performance skills for high school physics teachers, Master Thesis, King Khalid University, Saudi Arabia.

Attia, Mohsen Ali, 2015: Thinking Types, Its Skills and Educational Strategies, Dar Al-Safa, Amman.

Dikra, Sarmad Bahjat, and others, 2019: A training program for chemistry teachers on the basis of the knowledge economy and its effect on the productive thinking of their students, Journal of Educational and Psychological Paper, Volume (16), Issue (60).

Faiz Salem Abd, 2016, Building a training program for physics laboratory instructors on virtual laboratories and its effect on their technological enlightenment and the theoretical and practical performance of their students, a thesis submitted to the Board of the College of Education for Pure Sciences - Ibn Al-Haytham - University of Baghdad, which is part of the requirements for obtaining a Ph.D. in Philosophy in Education.

ITEA \& Technology for All Americans Project "TAAP", 2007"Technological literacy for All: A Rationale and structure for achievement and attitude in chemistry. International Online Journal of ITEA. 
Muhammad, Afrah Yassin, (2015): (Building an educational program _ learning according to the concepts of renewable energy and nanotechnology and its impact on technological enlightenment and scientific moral awareness among students of the Department of Chemistry), unpublished $\mathrm{PhD}$ thesis at Baghdad University / College of Education for Pure Sciences - Ibn Al Haytham.

Pintrich, P.R., 2000. The role of goal orientation in self-regulated learning. In Handbook of self-regulation (pp. 451-502). Academic Press.

Sabri, Maher Ismail, (2005): Scientific and Technical Enlightenment: Introduction to Education in the New Century, 1st Edition, Arab Bureau of Education for the Gulf States, Riyadh.

Sabry, Maher Ismail and Hamed, Muhammad Abul-Fotouh (2004): "Development of technology curricula and the development of thinking for the preparatory stage in light of the fields of technological enlightenment and its dimensions", the Eighth Scientific Conference of the Egyptian Society for Scientific Education "The absent dimensions in science curricula in the Arab world" Ismailia 25 July 28, Journal of the Egyptian Association for Scientific Education, Volume Two Sabry, Maher Ismail and Kamel, Moheb Mahmoud, (2000): “Technical Enlightenment: Its Concept and Ways to Achieve It", Journal of Science and Technology, p. 55, King Abdulaziz City for Science and Technology,

Sabry, Maher Ismail and Salah El-Din Mohamed Tawfiq, (2005): Technological Enlightenment and Modernization of Education, 2nd Edition, Modern University Office, Alexandria.

Suleiman, Samah Abdel-Hamid: 2016: The effectiveness of a program based on selforganized learning strategies in developing achievement, mathematical thinking and the trend towards self-learning among primary school students, Mathematics Education Journal, Volume 19, Issue 5, College of Education, Port Said University. 
Assist. Prof.dr. Etmad Naji. Fayadh alzobai \& Dr. Sameerah Adnan Thrther A-Qaisi

Volume (4) No. (4) 2021

Thinkx Inte llectual Capital IPInc. 2012.productive THining Fundamentals participant workbook.

Zaqout, Shaima Mahmoud, (2013): (The level of technological enlightenment and its relationship to classroom performance among science teachers in the higher basic stage in the Gaza governorates) Unpublished Master Thesis, Al-Azhar University / Gaza College of Education, Palestine. 
